\title{
The Academic Senate and University Governance in Canada
}

\section{GLEN A. JONES* \\ Ontario Institute for Studies in Education of the University of Toronto}

\section{THERESA SHANAHAN}

York University

\section{PAUL GOYAN}

Ontario Institute for Studies in Education of the University of Toronto

\section{ABSTRACT}

This study examines the academic senate within the context of university governance in Canada. Data were obtained from a survey of university senate secretaries on senate structure, composition, and operation, and from a survey of senate members on their perceptions of the senate, their role as senate members, and the nature of their work. The study raises concerns over the effectiveness of the senate and suggests a need to review the senate and its role in contemporary university governance within the context of the current Canadian higher education environment.

\footnotetext{
* Glen A. Jones is a professor and Paul Goyan is a graduate student in the higher education program at the Ontario Institute for Studies in Education of the University of Toronto. Theresa Shanahan is an assistant professor in the Faculty of Education at York University.
} 


\section{RÉSUMÉ}

La présente étude examine le sénat académique dans le cadre de la gouvernance des établissements universitaires au Canada. Des données ont été obtenues à partir d'une enquête menée auprès de secrétaires de sénats universitaires sur la structure, la composition et le fonctionnement des sénats ainsi qu'à partir d'une enquête menée auprès de membres de sénats sur leurs perceptions du sénat, leur rôle en tant que membres de ce dernier et la nature de leur travail. Cette étude soulève des préoccupations sur l'efficacité du sénat et propose la nécessité de réexaminer celui-ci ainsi que le rôle qu'il joue dans la gouvernance des établissements universitaires contemporains, et ce dans le contexte de l'environnement actuel de l'enseignement supérieur au Canada.

\section{INTRODUCTION}

University governance has become an important international issue in higher education (Amaral, Jones, \& Karseth, 2002a; De Boer, Goedegebuure, \& Meek, 1998; Gerard, 2003; Hirsch \& Weber, 2001; Tierney, in press; UNESCO, 2000). Shifting relationships between universities and the state have frequently created new challenges for institutional decision-making and governance arrangements. The significant reforms in higher education policy that have taken place in many jurisdictions over the last few decades have "led to fundamental changes in how institutions decide what they will do and how they will do it" (Reed, Meek, \& Jones, 2002, $\dot{\mathrm{p}}$. xv). At the same time, university governance has received relatively little attention in the higher education research literature until quite recently, and most of what has been written on the topic is not grounded in empirical research. The relatively small numbers 
of research studies that have been published have tended to focus on governing boards (in those jurisdictions where they exist), or on governance mechanisms associated with finance/resource allocation issues (Hardy, 1996; Tierney, in press). There have been surprisingly few empirical studies of academic governance in any system, including the United States (Center for Higher Education Policy Analysis, 2003), and none in Canada except for surveys of senate composition in the early 1970s.

This paper examines the academic senate within the context of university governance in Canada. We present data from a national study of Canadian university senates that involved two components. The first phase focused on the collection of data from university senate secretaries on the basic structure, composition, and operation of Canadian university senates. In the second phase, individual members of university senates were surveyed in order to obtain data on their perceptions of the senate, their role as senate members, and the nature of their work.

While we recognize that there is some variation in institutional terminology, for the purpose of this paper we use the word "senate" as a generic term referring to the senior, central academic decisionmaking body of a university. For institutions with a bicameral governance structure, the term is used to refer to the senior academic body that operates in parallel with the governing board. For institutions with a unicameral governance structure, the term is used to refer to a senior decision-making body that has been assigned some degree of responsibility over academic matters by the central governing body.

We begin by discussing university governance in Canada and providing a brief overview of the literature on this topic, followed by a description of the research design of this study and the presentation of findings. We conclude the paper with a discussion of issues associated with the academic senate and university governance in Canada. 


\section{UNIVERSITY GOVERNANCE IN CANADA}

The 1906 Royal Commission on the University of Toronto provided a clear rationale for the development of bicameral governance structures in Canadian universities (Cameron, 1991; Jones, 1996; Jones, Shanahan, \& Goyan, 2001). In reviewing the relationship between the University of Toronto and the Government of Ontario, the Commission argued that the University should be "divorced" from "the direct superintendence of political powers" and that Government authority over the institution should be delegated to a corporate board, largely composed of respected citizens appointed by government (Alexander, 1906, p. 276). At the same time, the Commission argued that the academic senate, composed primarily of senior scholars and academic administrators, should be retained, and that there should be a division of responsibility between the corporate board, assigned authority for the "administrative affairs" of the institution, and the senate, assigned responsibility for "academic affairs." While several other institutions had already experimented with bicameral structures, the report of the Royal Commission provided a clear framework for bicameral governance and the Act drafted by the Commission was quickly approved by the Government of Ontario. This Act, in turn, was used as a model by the emerging institutions in Western Canada. By the 1950s, almost all Canadian universities had adopted some form of bicameral governance structure. ${ }^{1}$

While the governance model, which emerged in the early years of the twentieth century, had largely been an attempt to clarify university-government relations while retaining some element of external accountability, the new pressures for change, which emerged in the $1960 \mathrm{~s}$, represented a demand for greater internal accountability to university constituencies. Faculty and students demanded a greater role in university governance as well as more 
open and transparent governance structures. Almost every Canadian university reviewed its governance arrangement during the period from 1964 to 1972. The governance reform process was influenced, at least in part, by a national study conducted by Sir James Duff and Robert Berdahl (1966). Duff and Berdahl argued that the reform of university governance could be accomplished within the framework of bicameralism: faculty should have a voice on university governing boards, students should have a voice on university senates, there should be more interaction between senates and boards, and the entire governance process should become more open and transparent. The actual changes that took place varied by institution, but almost all universities revised their governance structures to allow for faculty and student representation on the governing board and increased student representation on the university senate. By the early $1970 \mathrm{~s}$, most university senate meetings were open to the general public and university boards began to adopt similar (though more limited) procedures in order to increase the transparency of the decision-making process (Houwing \& Kristjanson, 1975; Houwing \& Michaud, 1972). The University of Toronto went its own way, abandoning bicameralism in favour of a unicameral structure (Commission, 1970).

When the governance reform movement ended in the early 1970 s, so did research on Canadian university governing boards and senates. However, interest in governance arrangements was reawakened in the mid-1970s by the movement towards faculty unionization on many university campuses and, more recently, by concerns regarding the capacity of institutional decision-making structures to respond to new demands for accountability within the fiscal realities of the 1990s (Hardy, 1996). If the governance reform process represented an attempt to create a balanced form of participatory decision-making, then faculty unionization, it has been argued, shifted that balance in favour of the professoriate (Cameron, 
1992). Even those directly involved in the movement towards unionization have speculated that the development of faculty unions may have reduced the power of the university senate (Penner, 1994). In terms of contemporary concerns regarding university governance structures, Cameron has argued that Canadian universities lack the capacity to make the big, difficult decisions required in order to respond to both internal and external pressures (1992), several provincial government studies have raised questions concerning university accountability and the role of governance structures (Task Force on University Accountability, 1993), and a Manitoba review argued that the current decentralized, participatory governance structures are inefficient since faculty members are devoting large amounts of time to committee activities when this time could be spent more productively in teaching or research (University Education Review Commission, 1993).

These concerns, combined with the fact that there have been no published empirical studies on university governance in Canada in the last two decades, led Glen Jones and Michael Skolnik to conduct a national study of Canadian university governing boards in 1994-95 (Jones \& Skolnik, 1997). That study involved two components: a national survey of board secretaries to collect data on board composition and structures, and a national survey of board members focusing on the work of board members, their perceptions of the role of board members, and their perceptions of the role of the board. Aside from obtaining data on board composition and the demographic characteristics of board members (age, gender, occupation), Jones and Skolnik found, for example, that board members believed that they had the knowledge and background information necessary to make decisions. In addition, few differences were found between internal and external members of the board in terms of their perceptions of the role of the board and their role as a board member, though internal members were generally more critical 
of the work of the board than external members. At the same time, there was clearly a degree of ambiguity in terms of the role of the board in academic decision-making (including both bicameral and unicameral institutions) and in the relationship between the board and the senior academic decision-making body. This study builds on Jones and Skolnik's analysis of university governing boards by obtaining parallel information on Canadian university senates.

The fact that most Canadian universities have a senate created under institution-specific charter legislation suggests that this body is assigned a formal role in institutional governance. In addition to this formal governance role, it has been suggested that the senate may play a variety of latent organizational functions (Birnbaum, 1989). The senate may play an important symbolic function (commitment to professional values, community decision-making, etc.), it may provide status to members, it may function as a "structural garbage can" where issues can be dumped with the understanding that no decisions will be made for some time, it can act as a scapegoat for the ineffectiveness of other bodies or academic administrators, and it may play a stabilizing role within the university community by maintaining rituals and generally inhibiting the ability of the organization to change (or at least change quickly) (Baldridge et al., 1986). In other words, while it is important to understand the role of the senate as an academic decision-making body (and the boundaries of this role in relation to the board and academic administration), it is also important to recognize that the senate may fulfill other latent functions within the university as an organization.

The literature is well developed in the area that applies organizational theory to the study of university and college decisionmaking, offering different metaphors to characterize the tenor of decision-making that takes place: the collegium, the bureaucracy, and the political arena grounded respectively in notions of community, position or expertise authority, and pluralistic politics (Rhoades, 
1992). The bureaucratic or managerial view of university decisionmaking portrays the senate as an academic management board. Drawing on Max Weber's (1947) work on bureaucracies, this model identifies some of the prominent bureaucratic features of university decision-making as: organized under state charter; formal hierarchy; formal channels of communication; definite authority relations; and formal policies, rules, record keeping, and the specialization of roles for the decision-making process. Rhoades (1992) and Hardy (1996) further distinguish this type of decision-making into professional and managerial bureaucratic models arguing that the professional model is dominated by academics and authority is based on professional expertise, whereas the managerial model is dominated by administrators and authority is rationally and legally based on position. Although they are both bureaucratic, the form of organization and control differ with the managerial bureaucracy having a more vertical chain of command compared to the flatter professional bureaucracy where professionals govern themselves and are linked together in loose confederations. Hardy maintains these models are not mutually exclusive and often co-exist at different locations within a university (Hardy, 1996).

By contrast, the political model of university governance suggests that the senate is a forum for the articulation of interests and "for the resolution of a wide range of issues involving the mission and operation of the institution" (American Association for Higher Education, 1967, p. 57). Underpinning this model is a pluralistic theory that emphasizes multiple groups with contradictory interests, values, and views that exist within a political dynamic of conflict and competition (Baldridge et al., 1986). Governance under this model occurs by negotiation, lobbying, and coalition forming. Leadership is exercised by mediation and strategy rather than by the exercise of formal authority. The reverse side of the political model is the collegium that emphasizes non-hierarchical, co-operative decision- 
making with a high degree of faculty involvement in decisionmaking. Whereas in the political model self-interest prevails, in the collegium interests are integrated by a consensus building process (Hardy, 1986). Decisions are made by the "community of scholars" (Baldridge et al., 1986).

Absent in much of the literature on models of decision-making in university governance are studies which attempt to capture, understand, and characterize the dynamic decision-making processes, as opposed to the static decision-making structures in the models described above (a distinction pointed out by Hardy, 1996). In particular, research is lacking in studies that take these models of decision-making to the floor of the senate in Canadian universities in order to determine how decision-making actually takes place, by whom, and in what fashion. This study attempts to address this gap by presenting data on composition, role, and structure of Canadian senates as reflected in both the legislative and regulatory documents, as well as in the perceptions of the senate members themselves.

\section{RESEARCH DESIGN}

The research design for this project involved two phases. The first phase of the study focused on obtaining data on the composition, organization, and role of university senates. A questionnaire was developed in the summer and fall of 1998, reviewed by several individuals who are members of, or work with, academic decisionmaking bodies, and then translated into French to create a bilingual survey package. Each survey package included a bilingual covering letter explaining the objectives and ethical protocols of the project, a bilingual questionnaire, and a return envelope. With two exceptions, the questionnaire asked for public domain information on university senates, and respondents were encouraged to forward charters, handbooks, regulations, and other relevant documents that might 
provide the researchers with a more detailed understanding of the organizational arrangements for academic decision-making. The first exception involved a request for the opinion of senate secretaries on important issues, and respondents were assured that responses to this question would be treated in such a way so that no individual or institution could be identified in the reporting of this data. The second exception involved a request for institutions to participate in the second phase of the study by either providing direct contact information on senate members, or allowing the researchers to provide survey packages to the senate secretary for distribution to senate members.

A list of institutions was obtained using the Universities Telephone Directory produced by the Association of Universities and Colleges of Canada. The sample population included all independent degreegranting institutions in Canada (including university colleges) listed in the AUCC directory, but excluded affiliated institutions, institutions that do not award secular degrees, and the Royal Military College. A total of 67 institutions were identified and questionnaire packages were mailed in November of 1998. Responses were received from $42^{2}$ institutions for a response rate of $63 \%$. Responses were received from institutions in all Canadian provinces except Saskatchewan. There are no degree-granting institutions in the three Canadian territories.

The second phase of the study was conducted in 1999-2000 and involved a survey of all senate members at institutions participating in the first component of the study. Thirty-eight institutions agreed to participate and bilingual questionnaires were distributed to 2,250 senate members. A total of 869 responses were received for a response rate of $40 \%$ (after adjusting for questionnaires that were undeliverable). The second phase was designed to increase our understanding of senate members (e.g. constituency, age, gender, educational background, and occupation), their work and their perception of the senate, and their role as members. 
Descriptive statistics were used to analyze data obtained from the questionnaires of the senate members to yield a profile of senate members and to identify patterns in their responses. Statistical cross-tabulations were utilized to determine whether there were differences in response by constituency, institution, and/or gender. For the purposes of data analysis, categories of constituencies were developed into five main groupings. Constituencies internal to the university included: faculty; senior administrators, which consisted of presidents, vice-presidents, deans and other senior administrators; students; support and other university staff. A single "external" category was used, which included all members from constituencies outside of the university, including alumni, government appointments, and other external members.

\section{Data Obtained from Senate Secretaries}

Senate secretaries were asked to provide information on the composition of the senate and these data are summarized in Table 1. For most institutions the composition of the senate is specified in the legislative charter, though for some universities the senior academic body was created under the authority of the governing board. Faculty are the largest category of members of university senates, comprising approximately $44 \%$ of the total membership, and students are the second largest membership category (18\%). All university senates include faculty and student members. The ratio of faculty to students sitting on the academic decision-making body varied widely. The largest ratio was found at Augustana where the academic decisionmaking body had only one student sitting on it but 51 faculty and 4 other senior administrators who had faculty status. The second largest ratio was found at Athabasca where the faculty outnumbered the students 7.5 to 1 on the academic decision-making body. In contrast, the number of faculty members (excluding academic administrative members who may also hold faculty appointments) 
is roughly equal to the number of student members of the General Faculties Council at the University of Alberta. The average ratio of total faculty membership to total student membership across the senates surveyed was 2.4 to $1 .^{3}$

The vast majority of university senates include ex-officio positions for senior university administrators, including the university president ( $90 \%$ of senates), vice presidents and deans (76\% of senates), and other senior administrators (83\% of senates). In aggregate terms, these administrative positions represent almost one-quarter of total senate membership. Other categories of membership included staff, representatives of the university board, representatives of affiliated colleges, alumni, and government appointees. There were also a number of idiosyncratic appointment categories, largely based on the unique history of some universities that we categorized as "other."

Of the 41 senates included in this analysis, the average number of voting members per senate was 61 . The largest senate participating in this study was at York University (192 members) and the smallest was at Sudbury (10 members). Comprehensive research universities tend to have larger senates than smaller, primarily undergraduate universities. Similarly, there appears to be a trend towards smaller senates in newer institutions. For example, the academic decisionmaking body at each campus of the University of Quebec is less than 20. The same holds true for Athabasca University and the new university colleges in British Columbia.

Since the average size of a university senate in Canada is rather large standing at 61 members, it is not surprising that most senates (55\%) have some form of executive committee. These committees are frequently assigned responsibility for establishing the agenda for senate meetings, steering matters through the senate committee process, and, in some situations, acting on behalf of the senate during the summer months. The average number of senate executive 
Table 1

Senate Membership by Category of Appointment

\begin{tabular}{lcc}
\hline Category & $\begin{array}{l}\text { Percentage } \\
\text { of All Senate } \\
\text { Members }\end{array}$ & $\begin{array}{l}\text { Percentage of } \\
\text { Senates } \\
\text { Reporting } \\
\text { Members in this } \\
\text { Category }\end{array}$ \\
\hline Faculty & 44 & 100 \\
Students & 18 & 100 \\
Vice Presidents/Deans & 12 & 76 \\
Other Senior Administrators & 11 & 83 \\
Staff & 6 & 54 \\
Board Representatives & 3 & 49 \\
Affiliated Colleges & 2 & 27 \\
Others & 2 & 22 \\
Alumni & 2 & 34 \\
President/Rector & 2 & 90 \\
Government Appointment & 1 & 10 \\
Chancellor & 1 & 41 \\
\hline
\end{tabular}

Note: Three incomplete responses were excluded from this analysis $(n=42)$. These figures represent voting membership only. Data on senate composition was obtained from an open-ended question and then collapsed to obtain broad categories. These categories are based on descriptions of senate composition and therefore provide data on organizing principles associated with senate membership, but the categories should not be viewed as mutually exclusive. For example, composition of the Augustana University College body includes all faculty and therefore the president and other senior academic administrators are members because of their faculty status and are listed as faculty in the table. The "Other Senior Administrators" category includes senior administrators not included in other categories, such as the registrar, directors, etc. Preliminary data from this analysis, in a modified form, was previously published in Jones, Shanahan, \& Goyan, 2001. 
meetings per year is eight. At Athabasca University and the University College of the Fraser Valley this executive committee is composed of only three members, while at some other institutions the executive committee is quite large and includes representation from a variety of constituencies. Approximately three-quarters of university senates (30 of 38) are chaired by the university president. Other chairs are elected by, and from the membership of, the senate.

The role and responsibilities of the senate are usually defined in the university's charter legislation, though 7 respondents $(17 \%)$ noted that the role of the senate is not described by the university's act or by provincial legislation. At these institutions, the senate was created under the authority of the governing board. Most respondents (31 or $79 \%$ ) indicated that there are university constitutional documents or bylaws that further clarify the role and responsibilities of the senate, though we noted that most of these documents seem to focus on governance procedures rather than on the duties or responsibilities of the senate.

There is considerable variation in the role and responsibilities explicitly assigned to the senate at Canadian universities. These are summarized in Table 2. While at most institutions the senate has authority over major academic decisions, such as the approval of new academic programs, there are significant differences in the range of responsibilities and the level of authority. At some institutions the senate has been assigned a broad role of advising the board on academic matters, while at others the senate has a more narrowly defined mandate and executive responsibility over specific areas of decision-making. A majority of respondents (20 out of 39 completed responses, or $51 \%$ ) indicated on the survey that the senate plays some form of formal role in the university's annual budget or financial allocation process, but this finding also reveals that for $49 \%$ of the universities included in this study, the senior academic decision-making body plays no formal role in important 
financial decisions. It should be noted, however, that an explicit, legislatively-defined, senate role with respect to the institutional budgetary process could be found in the legislative documents of only seven of the institutions surveyed (18\%).

Approximately $33 \%$ of respondents indicated that all senate meetings are open to the public, and an additional 55\% indicated that most meetings are open but that some matters may be dealt with in closed sessions. Ten percent of senate secretaries indicated that senate meetings are not open to the public. The average number of senate meetings held each year was 9 .

We also asked senate secretaries if the university provides orientation materials or sessions for new members. Almost twothirds of the universities included in this study provide at least some orientation information to new members, though the orientation process frequently involved simply sending new members a copy of the senate handbook or bylaws. Only a small number of institutions hold an orientation session or workshop for new members. Approximately $38 \%$ (18 of 40 who completed this question) do not provide any orientation materials to new members.

Finally, we asked senate secretaries to describe what were, in their opinion, the most important issues and problems related to the role and work of university senates in the context of university governance. While recognizing that the opinions of senate secretaries may not necessarily represent the interests of the broader university community, these individuals have a unique vantage point for observing the work of these decision-making bodies. Three major themes emerged from the responses to this question: the challenge of academic decision-making in the context of fiscal restraint; the problem of vested interests and territoriality; and the challenge of change. 
Table 2

Roles, Responsibilities, and Powers Explicitly Assigned to Academic Senate

\begin{tabular}{lcc}
\hline Roles/Powers & $\begin{array}{l}\text { Number of } \\
\text { Respondents } \\
(\mathbf{N = 3 8 )}\end{array}$ & $\begin{array}{l}\text { Percentage } \\
(\%)\end{array}$ \\
\hline $\begin{array}{l}\text { Approve courses and establish } \\
\quad \text { admission standards }\end{array}$ & 34 & 89 \\
Set educational policy & 33 & 87 \\
Confer degrees and other credentials & 32 & 84 \\
Conduct affairs of senate & 29 & 76 \\
Award scholarships and other prizes & 27 & 71 \\
Oversee student evaluation and exams & 26 & 68 \\
Create faculties, schools, and & 22 & 58 \\
$\quad$ departments (generally with Board & & \\
$\quad$ approval) & 20 & 53 \\
Oversee academic appeals and student & 26 & \\
$\quad$ discipline & 18 & 47 \\
Select (or recommend to Board) & & \\
$\quad$ academic appointments & 17 & 45 \\
Set library policy & 7 & 18 \\
Recommend senior appointments & & \\
to Board & & \\
\hline
\end{tabular}

\section{Academic Decision Making in the Context of Fiscal Restraint}

The most frequent issue or concern noted by senate secretaries was the challenge of making academic decisions and maintaining academic standards in an environment of decreasing financial resources. As one respondent noted:

The Canadian Journal of Higher Education

Volume XXXIV, No. 2, 2004 
The bicameral form of governance at [this university] works reasonably well under normal circumstances. However, under circumstances of financial exigency and constraint the necessary priority given to monetary matters diminishes severely the effectiveness of the senate, without any reduction of the formally stated powers of that body. The focus of interest and attention shifts from academic concerns to financial ones, moving the dominant exercise of power to the Board.

Others noted the challenge of trying to ensure that financial issues are given appropriate attention within the process of academic decision-making. In some situations academic decisions are made in isolation from financial decisions, and secretaries noted that it is difficult to find the most appropriate interface between the senate, and its role in academic decision-making, and the board, with its central role in financial and administrative issues.

Aside from issues related to the relationship between the senate and the board within a bicameral governance structure, several senate secretaries noted that financial difficulties have simply made the job of the senate more difficult. One respondent wrote that the university's financial situation "forces us to rationalize our programs and our academic activities."

\section{Vested Interests and Territoriality}

A substantial number of senate secretaries indicated that senate members frequently take positions designed to benefit their personal or sectoral interests. One respondent wrote:

When we have decisions and questions of an academic nature, certain members and constituencies will use it as a vehicle to promote their party - not realizing the total impact on the university as a whole. They will not always separate their personal participation in decisions that affect the function and interests of the larger institution. 
Another identified the tremendous challenge associated with attempting to encourage different constituencies (e.g. students, faculty, administrators) and academic units to understand each other. One respondent indicated that it was very difficult to "get Senators to overcome sector loyalties so as to act in the best interest of the University as a whole" and that faculty exhibited a lack of respect or understanding for those outside of the academic realm, especially university support staff. It was noted that the decision-making process often involves conflict between various constituencies or academic territories, in contrast to "traditional" descriptions of academic decision-making based on collegiality and consensus.

\section{The Challenge of Change}

A third theme emerging from the issues identified by board secretaries involved the challenge of change. One aspect of this theme involved the reluctance of the senate to deal with change: a reluctance that at least some senate secretaries believed was inappropriate in a rapidly changing higher education environment. One respondent concluded "their inability to change may make them obsolete." Another noted that "academic snobbery" prevented the senate from responding to demands from the changing student population or exploring issues such as advanced credit standing.

The second aspect of this theme involved the challenge of establishing new types of policy as required in a rapidly changing environment. For example, several respondents noted the senate was now involved in new policy areas, such as the utilization of information technology and issues of accountability for academic programs that involved quite complex issues. One respondent also noted that the senate was finding it difficult to reform itself in order to be more representative of the broader community: "How [should the senate] manage the selection of Senators so that younger faculty and minorities are chosen?" 


\section{DATA OBTAINED FROM SENATE MEMBERS}

\section{Demographics}

In the first part of the Phase Two survey, senate members were asked to provide demographic information about themselves including their age, sex, highest level of education achieved, their history on governing boards, their present occupation, as well as the basis for their senate membership. This provided us with a profile of the senate membership.

Over two-thirds of senate member respondents were male (73\%). Across constituencies men outnumbered women on the senate by 2.6 to 1 . There were more male than female respondents in all constituencies (i.e., faculty, senior administrators, students, and external) except the "support and other" category, where there were slightly more women than men.

The average age of senate members was 49 years, although most faculty on senate fell between the ages of 50 to 64 years. The vast majority of members reported holding graduate degree $(84 \%)$ and a large majority $(65 \%)$ had earned doctoral degrees. Students were the least credentialed constituency on the senate and typically had an undergraduate degree. Less than half of the respondents (40\%) had been a student at the university where they were now serving on the senate. Less than a quarter of the respondents had experience serving on the governing board of the university.

Most of the senate member respondents reported coming from constituencies within the university (93\%). Faculty represented the largest category of respondents $(49 \%)$. Senior administrators represented $30 \%$ of the respondents (i.e., presidents, vice-presidents, deans, and other senior administrators). The largest portion of the senate membership reported being elected by their constituency (61.4\%) and a substantial proportion were ex-officio appointments 
(22\%). Only a very small portion of senate members were appointed by government (less than $2 \%){ }^{4}$

\section{The Work of Senate Members}

In the second portion of the survey, senate members were asked about their work as members of the senate. The average length of senate membership of respondents was four years. The longest reported membership was 32 years. Senate members reported spending an average of 6.5 hours per month preparing for and attending meetings. The findings suggest that senate members strongly perceive themselves as active and informed members who know the organizational structure of the university (74\%). Across gender, this perception was stronger for women (74\%) than for men $(63 \%)$. Across constituency categories, senior administrators $(77 \%)$, students $(75 \%)$, and faculty (74\%) also responded very positively that they were informed and active members of senate. While almost three-quarters $(74 \%)$ of senate members believe that the university provides them with sufficient information to make their decisions, $50 \%$ also indicated that the orientation they received as a new senate member did not adequately prepare them for their work on the senate (and an additional one-quarter of respondents provided a neutral response to this question.)

By category, senior administrators (72\%) responded most strongly that they have the knowledge and ability to influence the senate. While overall most members agreed they were able to influence senate decisions (55\%), the belief was not consistent across all occupational categories. For example, $37 \%$ of students responded that they did not have influence on senate decision-making, while $32 \%$ of student respondents indicated that they did have influence, and a similar number provided a neutral response (31\%). 


\section{Role}

In order to obtain senate member perceptions on the role of the senate, the questionnaire included a series of paired statements. Respondents were asked to indicate their level of agreement/ disagreement on whether the senate should fulfill a particular role or function, followed by a question on whether the senate does fulfill that role or function.

Concerning the role of the senate, $69 \%$ of respondents agreed that it should confine itself mainly to academic matters, although agreement was highest among administrators (83\%) and lowest among students (49\%). Almost the same percentage of respondents $(68 \%)$ agreed that the senate does confine itself mainly to academic matters. There was very strong agreement $(90 \%)$ that the senate should be the final authority for approving academic policies, whereas in practice only $74 \%$ agreed that this was the case.

Respondents indicated their agreement that the senate should play a role within the university in four areas as follows: establishing research policies $(78 \%)$; determining strategic research directions $(56 \%)$; determining priorities for fundraising and development $(51 \%)$; and, determining the future direction of the university (89\%). Administration support for the senate playing a role in these areas was lower than that of faculty in all cases. Most notably, whereas $56 \%$ of faculty agreed that the senate should play a role in determining priorities for fundraising and development, only $36 \%$ of administrators agreed.

Respondents were also asked to indicate whether the senate does play a role in these four areas and the responses indicate a substantially more limited role in practice. Although $44 \%$ of respondents agreed that the senate does play a role in establishing research policies, a majority (54\%) disagreed that the senate plays a role in determining strategic research directions. Similarly, only $43 \%$ agreed that the 
senate does play a role in determining the future direction of the institution, whereas $65 \%$ disagreed that the senate plays a role in determining priorities for fundraising and development.

Respondents indicated very strong agreement (89\%) that the senate should play a role in determining the future direction of the university. However, it is difficult to understand how this role might best be realized if, in most instances, the senate is neither involved in determining priorities for fundraising and development nor in the budget process. Although 59\% of respondents agreed that the senate should play a major role in the university's budget process, 57\% disagreed that the senate actually does play such a role. A majority of faculty (67\%) supported a budget role for the senate, whereas only $37 \%$ of administration supported such a role.

\section{Accountability and Effectiveness}

In recent years, there has been significant attention paid to issues of accountability in universities and the broader public sector. Almost all respondents (93\%) agreed that the senate should ask "tough questions" of senior university administrators. However, only $49 \%$ agreed that the senate does in fact ask "tough questions." A majority of administration (91\%) agreed that "tough questions" are asked, whereas only $43 \%$ of faculty and $33 \%$ of students believed this to be the case. Similarly, a large majority $(93 \%)$ of respondents agreed that the senate should periodically review its performance, although $63 \%$ do not believe that this actually occurs.

When asked to assess the senate as a decision-making body, only $44 \%$ of respondents agreed that it is effective. A majority of respondents $(60 \%)$ agreed that the senate primarily approves decisions made elsewhere. Almost two-thirds (68\%) of respondents agreed that it is difficult for the senate to make decisions involving significant change. However, $47 \%$ of respondents agreed that 
the senate plays an important role in facilitating the exchange of information between component parts of the university. Almost two-thirds $(65 \%)$ of respondents agreed that the senate plays an important role as a forum for discussing important matters.

\section{Representing Interests}

Respondents were asked the degree to which their role on the senate is to represent the interests of a specific constituency (internal or external), the best interests of the broader society, and/or the university as a whole. A majority of respondents agreed that their role was to do all three, although the strongest support was for representing the best interests of the university (95\%), followed by the best interests of society (68\%), and a specific constituency $(54 \%)$. In terms of representing a specific constituency, students agreed most strongly that this was part of their role $(83 \%)$ and administration agreed least with this perspective (43\%). Although support was strongest for representing the best interests of the university, only $49 \%$ of respondents agreed that with most issues it is clear what course of action is in the institution's best interest. While both men and women agreed that it was clear with most issues what course of action was in the best interest of the university as a whole, a larger percentage of men $(51 \%)$ responded positively than women $(44 \%)$.

With regard to most issues, $42 \%$ of respondents agreed that internal members of senate do not experience conflict supporting the interests of the university and those of their constituency, whereas $32 \%$ disagreed and $26 \%$ were neutral. Similarly only $37 \%$ of respondents felt that external members experienced conflict.

A majority of respondents $(62 \%)$ agreed that a senate should play a role in lobbying for change in government policy; however, only $15 \%$ agreed that the senate does play such a role. Almost twothirds of respondents $(65 \%)$ agreed that the senate plays an important 
role as a forum for discussing important issues and $47 \%$ agreed that the senate plays an important role in facilitating the exchange of information between component parts of the university.

\section{Changing Autonomy and Authority}

Almost two-thirds $(65 \%)$ of respondents agreed that the division of responsibilities between the governing board and the senate is generally quite clear, although only $59 \%$ of faculty were in agreement compared to $73 \%$ of administration. A significant minority (39\%) of respondents agreed that the senate should have more autonomy from the university's governing board. Almost $64 \%$ of respondents disagreed with the statement that the authority of the senate is increasing in comparison to the university's administration and governing board.

Only $27 \%$ of respondents agreed that the role of the senate has been strengthened by the work of the faculty association or union. However, support among faculty (36\%) for this view was substantially higher than among the administration (18\%). When asked whether the influence of the faculty association or union on academic matters is increasing in comparison to the senate, more respondents disagreed (42\%) than agreed (26\%). However, whereas only $23 \%$ of faculty agreed that this was happening, $32 \%$ of administrations were in agreement.

\section{DISCUSSION}

This study provides important information on the composition and role of Canadian university senates and the perceptions of senate members on the senate, their role as senate members, and the nature of their work. One of the important findings of the study is that there are significant differences in the role and work 
of the senate by institution. The data that we have presented in this paper provides a national snapshot of Canadian university senates, but it is important to recognize the limitations associated with looking across institutions and providing a national perspective on what are, in functional terms, idiosyncratic institutional governance arrangements.

Given that the majority of Canadian universities have a bicameral governance structure in which the senate is assigned a formal role in institutional decision-making under government legislation, perhaps the most important overall finding of the study is that the majority of members do not believe that the senate is an effective decisionmaking body. Central to this issue is the senate's current role within the university. While it appears from our study that there is clarity among senate members regarding their responsibility in relation to the governing board and there is agreement on the senate's academic decision-making role, the findings suggest that there is ambiguity in terms of how "academic" decisions are defined and understood. Senate members believed that the senate should, but that it does not, play a role in terms of determining the future direction of the university, establishing research policies, determining strategic research directions, and determining priorities for fundraising and development. One might argue that these are core academic issues, and the limited role of the senate in these policy areas clearly suggests that there are important limitations in the degree to which the senate can monitor and influence the academic direction of the university. Many senate members clearly believe that the balance of influence over academic decision-making is shifting in favour of the university administration and the governing board.

Some of this ambiguity may simply be a function of the fact that most Canadian universities provide little in the way of orientation materials or programs for new senate members. New members may 
not be familiar with the parameters of their responsibility, or the process and structure of university governance and decision-making. Is their role one of representing the interests of a specific constituency, or making decisions that they view as being in the best interests of the university as a whole? The assumption of senate members' prior governance knowledge, coupled with their lack of orientation, is at least problematic and most certainly ensures a steep learning curve and a gap in the smooth, effective operation of the body between the tenures of outgoing and incoming senators. Compounding these concerns is the fact that few senates appear to devote any time or energy towards assessing their work or performance. New members are seldom provided with an orientation to their role, and experienced members are seldom provided with a formal opportunity to comment on how the work of the senate might be strengthened or improved.

Many might assume that the majority of senate members would be faculty - but our study suggests this is only true if one includes senior administrators under this category. While there are important differences in senate composition by institution, far less than fifty percent of senate seats at many universities are held by rank-and-file professors. If the senate is viewed as a governing body with oversight responsibility for academic policy, then the composition of the senate seems somewhat unusual, especially given the fact that more than one-quarter of all members are senior administrators who are generally making the day-to-day academic administrative decisions that the senate is charged with monitoring and/or overseeing. It is interesting to note that nearly three-quarters of senior administration ( $72 \%$ ) felt they were able to influence decisions compared to $55 \%$ of faculty, and only $32 \%$ of student members.

Perhaps a core issue related to senate composition is whether the balance of membership continues to make sense. At the time of the governance reforms following the Duff-Berdahl Commission, 
the emphasis was on increasing the role of constituencies within the university in decision-making. However, at that time "other voices" representing identities shaped by race and gender were not yet generally recognized as constituencies. Since the reforms of the late 1960 s and early 1970s, universities have become more sensitive to diversity, especially issues associated with gender and race-part of the panoply of individuals and groups marked by differenceand several senate secretaries noted the challenge of attempting to increase the representative nature of senate membership. The question is simply whether the assumptions that underscored decisions on the composition of the senate when it was last reviewed continue to be appropriate, especially since, at many universities, these decisions predated the tremendous rise in importance of, for example, parttime/sessional instructors, information technology professions, and equity officers in the day-to-day academic work of the university.

While the study clearly indicates that there are difficult problems associated with the senate at many Canadian universities, it is important not to lose sight of some of the more positive findings of the study. There is considerable agreement that the senate plays an important role in terms of providing a forum for communication. Most senate members define themselves as "active" and devote considerable time to this voluntary service activity. They agree that the senate should and does play an important role in terms of academic policy within Canadian universities.

\section{CONCLUSION}

This study provides important information on the role, composition, and functioning of Canadian university senates. It is the first study of its kind in Canada or elsewhere. Nevertheless, it is important to recognize that institutional differences limit the 
generalizability of our findings, in particular because each individual senate has different formal roles prescribed by legislation.

The findings from our study raise many questions: Does the composition of the senate still make sense in the context of current institutional realities? Are there ways of clarifying the role of the senate in the face of new policy issues and pressures? How should senates orient new members? What mechanisms or approaches might be used by the senate to assess and improve its performance?

There is evidence in our study to suggest that these governance issues should be reviewed. The matter is all the more urgent given the changes that have occurred in Canadian higher education policy in the last decade (Jones, Shanahan, \& Goyan, 2002; Shanahan $\&$ Jones, 2004). The role of the senate is extremely important within a contemporary discussion of Canadian higher education. The changing environment in which Canadian universities now function includes fiscal restraint and shifts in government funding mechanisms. Some provincial governments are linking a component of university funding to key performance indicators (KPIs) while also adopting targeted and matched-funding programs. Universities have necessarily reacted by increasing fundraising activities and industry partnerships to offset cutbacks and access government matching grant programs. Institutional and professorial entrepreneurship has resulted and is encouraged to the extent that it generates revenue for the university. In some Canadian provinces the new landscape also reflects shifts in student tuition and assistance policies that have included partial and full deregulation of tuition fees.

Taken together, these fiscal policies suggest an overall transfer of the cost of university education away from the government and towards the "consumer" or those who stand to benefit from the education (i.e. the students and private industry). Higher education policies have, in effect, opened up universities to the private sector 
and expanded degree-granting, allowing for increased competition within and between the university and college sectors. Governments in Canada (provincial and federal) are placing a greater emphasis on universities meeting labour market needs especially through vocational, skills-based, and technological curricula and programs. University research and development that feeds the economy has also been emphasized and favoured in higher education policy. Over the last two decades, governments in Canada have become increasingly concerned about ensuring and demonstrating institutional quality and accountability in all sectors. Higher education is no exception. Increasingly, universities and colleges have been asked to account for public funds (Jones, 1997; Jones, Shanahan, \& Goyan, 2002; Shanahan \& Jones, 2004).

Cumulatively, these trends suggest governments' use of market mechanisms in higher education to assist in resource allocation, to generate revenue, to address accessibility and accountability goals, and to meet labour market and economic needs (Shanahan \& Jones, 2004). This policy context has significant implications for university autonomy, in general, and the role of the senate and other central academic decision-making bodies, in particular. Universities are currently subjected to a variety of pressures and influences. On the one hand, it can be argued that the autonomy of Canadian public universities is diminishing as a function of targeted provincial support in some provinces that has the potential to steer the directions taken by the university, while on the other, several provinces are encouraging the development of "market forces" and institutional entrepreneurship (Jones \& Young, 2004). In either case, the university is facing increasing calls for mechanisms that demonstrate accountability and measure quality: calls which have triggered controversy and resistance as a response to concerns about institutional autonomy, academic freedom, and the appropriateness of importing business values into an education culture. 
These trends raise important questions concerning the role of central academic decision-making structures (Jones, Shanahan, \& Goyan, 2002). They present challenges for universities and require effective and immediate responsiveness on the part of governing bodies. Our findings suggest that senate's actual role in demonstrating accountability in such simple ways as through reviewing their own performance, or raising challenging questions of senior university administrators, falls short, even by senators' expectations. Given the increasing emphasis on quality and accountability in the current higher education context, this is an area where the work of senates might be rethought and strengthened.

Our study suggests that Canadian senates have an important traditional and symbolic role, but their practical and meaningful participation in important, defining university decisions is limited and perhaps even diminishing. The artificial and increasingly strained distinction between financial and academic matters which currently appears to divide the responsibilities of university governing bodies (senates and boards) compounds the problem (Jones, 2002). Our findings from the senate secretaries, as well as senate members, suggest a need for integration of the senate's role in academic decision-making with the board's role in financial and administrative matters. It is within this context that our study raises concerns over the effectiveness of the senate and suggests a need to review its role in contemporary university governance.

\section{Acknowledgements}

This is a revised version of two papers that were presented at annual meetings of the Canadian Society for the Study of Higher Education. We presented preliminary findings of the first phase of our study at the 1999 conference at the University of Sherbrooke, 
and findings from the second phase at the 2000 conference at the University of Alberta. The authors are grateful for the financial support provided by the Social Sciences and Humanities Research Council of Canada.

\section{Notes}

${ }^{\mathrm{L}}$ Laval University was an important exception. Its 1852 charter established a unicameral structure and this basic framework was retained until 1991.

${ }^{2}$ It is important to note that the University of New Brunswick has two senates: one for the Fredericton campus and one for the St. John campus. We treat these senates as two distinct bodies.

${ }^{3}$ This ratio is based on the relationship between these two explicit categories across the universities surveyed. We recognize that actual student and faculty numbers on the senate may differ as students and faculty may be present in other categories.

${ }^{4}$ The rest were appointed as board, senate, or organization representatives.

\section{References}

Alexander, W.J. (Ed.). (1906). The university and its colleges - The University of Toronto, 1827-1906. Toronto: The Librarian (University of Toronto).

Amaral, A., Jones, G.A., \& Karseth, B. (Ed.). (2002a). Governing higher education: National perspectives on institutional governance. Dordrecht: Kluwer Academic Publishers.

Amaral, A., Jones, G.A., \& Karseth, B. (2002b). Governing higher education: Comparing national perspectives. In A. Amaral, G.A. Jones, \& B. Karseth (Eds.), Governing higher education: National perspectives on institutional governance (pp. 279-298). Dordrecht: Kluwer Academic Publishers.

American Association for Higher Education. (1967). Faculty participation in academic governance. Washington, D.C.: American Association for Higher Education. 
Baldridge, J.V., Curtis, D.V., Ecker, G.P., \& Riley, G.L. (1986). Alternative models of governance in higher education. In $\mathrm{H}$. Peterson (Ed.) ASHE reader in organization and governance in higher education (pp. 11-27). Lexington, Mass: Ginn Press.

Birnbaum, R. (1989). The latent organizational functions of the academic senate: Why senates do not work but will not go away. Journal of Higher Education, $60(4), 423-443$.

Cameron, D.M. (1991). More than an academic question: Universities, government, and public policy in Canada. Halifax: Institute for Research on Public Policy.

Cameron, D.M. (1992). Institutional management: How should the governance and management of universities in Canada accommodate changing circumstances? In J. Cutt \& R. Dobell (Eds.), Public purse, public purpose: Autonomy and accountability in the groves of academe (pp. 167-192). Halifax: Institute for Research on Public Policy.

Center for Higher Education Policy Analysis. (2003). Challenges for governance: A national report. Los Angeles, CA: Center for Higher Education Policy Analysis, Rossier School of Education, University of Southern California.

Commission on the Government of the University of Toronto. (1970). Toward community in university government: Report of the Commission on the Government of the University of Toronto. Toronto: University of Toronto Press.

De Boer, H., Goedegebuure, L., \& Meek, L. (Eds.). (1998). New perspectives on governance. Special issue of Higher Education Policy, 1I(2/3), 103-235.

Duff, J., \& Berdahl, R. (1966). University government in Canada. Ottawa: Association of Universities and Colleges of Canada and the Canadian Association of University Teachers.

Gerard, S.M. (2003). Who are the actors in the government of French universities? The paradoxical victory of deliberative leadership. Higher Education, 45(1), 71-89.

Hardy, C. (1996). The politics of collegiality: Retrenchment strategies in Canadian universities. Montreal: McGill-Queen's University Press.

Hirsch, W.Z., \& Weber, L.E. (Eds.). (2001). Governance in higher education: The university in a state of flux. London: Economica.

Houwing, J.F., \& Kristjanson, M.M. (1975). Composition of governing bodies of Canadian universities and colleges, 1975. Ottawa: AUCC.

Houwing, J.F., \& Michaud, L.F. (1972). Changes in the composition of governing bodies of Canadian universities and colleges, 1965-1970. Ottawa: AUCC. 
Jones, G.A. (1996). Governments, governance, and Canadian universities. In J. Smart (Ed.), Higher education: Handbook of theory and research, Volume XI (pp. 337-371). New York: Agathon Press.

Jones, G.A. (Ed.). (1997). Higher education in Canada: Different systems, different perspectives. New York: Garland Publishing.

Jones, G.A. (2002). The structure of university governance in Canada: A policy network approach. In A. Amaral, G.A. Jones, \& B. Karseth (Eds.), Governing higher education: National perspectives on institutional governance (pp. 213-234). Dordrecht, The Netherlands: Kluwer Academic Publishers.

Jones, G.A., Shanahan, T., \& Goyan, P. (2001). University governance in Canadian higher education. Tertiary Education and Management, 7, 135-148.

Jones, G.A., Shanahan, T., \& Goyan, P. (2002). Traditional governance structurescurrent policy pressures: The academic senate and Canadian universities. Tertiary Education and Management, 8, 29-45.

Jones, G.A., \& Skolnik, M.L. (1997). Governing boards in Canadian universities. Review of Higher Education, 20(3), 277-295.

Jones, G.A., \& Young, S. (2004). "Madly off in all directions": Higher education, marketization, and Canadian federalism. In P. Teixeria, B.B. Jongbloed, D. Dill, \& A. Amaral (Eds.), Markets and higher education: Rhetoric or reality? (pp. 185-205). Dordrecht, The Netherlands: Kluwer Academic Publishers.

Penner, R. (1994). Unionization, democracy, and the university. Interchange, 25(1), 49-53.

Reed, M.I., Meek, V.L., \& Jones, G.A. (2002). Introduction. In A. Amaral, G.A. Jones, \& B. Karseth (Eds.), Governing higher education: National perspectives on institutional governance ( $\mathrm{pp} . \mathrm{xv}-\mathrm{xxxi}$ ). Dordrecht: Kluwer Academic Publishers.

Rhoades, G. (1992). Governance models. In B. Clark and G. Neaves (Eds.) The Encyclopedia of Higher Education, Vol. 2 (pp.1376-1384), Oxford: Pergamon Press.

Shanahan, T., \& Jones, G.A. (2004). The case of Ontario: The impact of postsecondary policy on Ontario. Presentation as part of a panel session entitled, Les Politiques de l'enseignement postsecondaire en Colombie-Britannique, en Ontario et au Québec. Annual Conference of the Canadian Society for the Study of Higher Education, Winnipeg, Manitoba, May 30 to June 1st.

Slaughter, S., \& Leslie, L. (1997). Academic capitalism: Politics, policies and the entrepreneurial university. Baltimore: John Hopkins. 
Task Force on University Accountability. (1993). University accountability: A strengthened framework. Toronto: Task Force on University Accountability.

Tierney, W.G. (in press). A cultural analysis of shared governance: The challenges ahead. In J. Smart (Ed.), Higher education: Handbook of theory and research, Volume XIX. Dordrecht: Kluwer Academic Publishers.

UNESCO Chair of Higher Education Management. (2000). International seminar on university governance and management: Lectures/Ponencias. Barcelona: UNESCO Chair of Higher Education Management, Technical University of Catalonia.

University Education Review Commission. (1993). Post-secondary education in Manitoba: Doing things differently. Winnipeg: Government of Manitoba.

Weber, W. (1947). The theory of social and economic organization. New York: Free Press. 